\title{
Effect of abomasal ferrous lactate infusion on phosphorus absorption in lactating dairy cows ${ }^{1}$
}

\author{
X. Feng, ${ }^{*}$ K. F. Knowlton, ${ }^{* 2}$ A. D. Dietrich, $†$ and S. Duncan $\ddagger$ \\ *Department of Dairy Science, \\ †Department of Civil and Environmental Engineering, and \\ ‡Department of Food Science and Technology, Virginia Polytechnic Institute and State University, Blacksburg 24061
}

\section{ABSTRACT}

The objective of this study was to evaluate the effect of ferrous lactate infusion on postruminal $\mathrm{P}$ absorption in lactating dairy cows. Four ruminally cannulated lactating cows were used in a $4 \times 4$ Latin square design with $14 \mathrm{~d}$ per period. Cows were fed a basal diet containing $0.39 \% \mathrm{P}$, providing $100 \%$ of the calculated $\mathrm{P}$ requirement. On $\mathrm{d} 8$ to 14 of each period, each cow was infused with $0,200,500$, or $1,250 \mathrm{mg}$ of $\mathrm{Fe} / \mathrm{d}$ in the form of ferrous lactate solution (ferrous lactate in $1 \mathrm{~L}$ of double-distilled water) into the abomasum. Infusate was formulated to approximate $0,2,5$, or $12.5 \mathrm{mg}$ of $\mathrm{Fe} / \mathrm{L}$ in drinking water with $100 \mathrm{~L}$ of water intake/d. Total fecal collection was conducted in the last $4 \mathrm{~d}$ of each period to measure nutrient digestion and excretion. Dry matter intake, milk yield, and milk composition were not affected by treatment. Digestibility of DM, $\mathrm{NDF}$, and nitrogen decreased linearly with increasing ferrous lactate infusion. Infusion of ferrous lactate did not affect intake and digestibility of total $\mathrm{P}$, inorganic $\mathrm{P}$, or phytate $\mathrm{P}$. In lactating cows, $\mathrm{P}$ absorption was not negatively influenced by abomasally infused ferrous lactate up to $1,250 \mathrm{mg}$ of $\mathrm{Fe} / \mathrm{d}$.

Key words: iron, ferrous lactate, phosphorus absorption

\section{INTRODUCTION}

Iron is an essential micromineral for cattle, but little research has been done evaluating its requirement in lactating cows in recent decades. It is common for $\mathrm{Fe}$ in ruminant diets to exceed animal requirements by 5 -fold or more (Spears, 2008). With the high content of Fe $(200 \mathrm{mg} / \mathrm{kg})$ in feedstuffs and soil, Fe deficiency is rare (Underwood and Suttle, 1999) and generally only observed in calves fed solely milk or milk replacer. The

Received January 21, 2013.

Accepted March 17, 2013.

${ }^{1}$ This project was supported by the John Lee Pratt Foundation, Virginia Tech.

${ }^{2}$ Corresponding author: knowlton@vt.edu primary regulation of the body's Fe status is at the point of absorption (Frazer and Anderson, 2005). Excessive $\mathrm{Fe}$ absorbed into the enterocytes is incorporated into the Fe storage protein ferritin in the enterocytes, which can be excreted out of the body as the cell is sloughed and excreted into feces.

Iron toxicity is also uncommon in adult cows except in extreme situations (Miller, 1981). Iron in forages is primarily in the form of ferric oxide, relatively insoluble and poorly absorbed (Hansen and Spears, 2009; Weiss et al., 2010). The NRC (2001) assigns an absorption coefficient of 0.10 to dietary Fe, with a maximum recommendation of $1,000 \mathrm{mg} / \mathrm{kg}$ of DM. Cows grazing pasture irrigated with high-Fe water $(17 \mathrm{mg} / \mathrm{L})$ had reduced milk yield and their feces were dark, frothy, and malodorous (Coup and Campbell, 1964). Cows grazing pasture irrigated with high-Fe water had greater BW loss than cows grazing pastures not irrigated by high Fe water.

Interactions with $\mathrm{Fe}$ may interfere with digestion and absorption of other nutrients. Steers fed high-Fe diets (1,000 $\mathrm{mg}$ of $\mathrm{Fe} / \mathrm{kg}$ of $\mathrm{DM}$ as ferrous sulfate) had lower ADG and darker rumen color, an indicator of Fe toxicity, than those fed low-Fe diets (100 mg of $\mathrm{Fe} / \mathrm{kg}$ of DM; Standish et al., 1971). Concentrations of $\mathrm{Cu}$ and $\mathrm{P}$ in plasma and liver were also reduced in the high-Fe group, but high $\mathrm{P}$ intake seemed to alleviate the negative effect of high Fe intake, with rumen color less dark in the high-P, high-Fe treatment. The observed interaction of dietary $\mathrm{P}$ and Fe was likely due to formation of insoluble complexes of $\mathrm{P}$ and $\mathrm{Fe}$ in the digestive tract (e.g., $\mathrm{FePO}_{4}$ ), decreasing the availability of both elements.

Iron in groundwater is primarily in the ferrous and dissolved form so it is more readily absorbed and potentially more toxic than the ferric oxide form common in feedstuffs (Standish et al., 1969; Thomas, 1970). Adult cows drink 90 to $150 \mathrm{~L}$ of water per day, and anoxic or anaerobic groundwater may contain ferrous $\mathrm{Fe}$ in milligrams-per-liter concentrations, making water a potentially significant source of available iron. Water Fe higher than $0.3 \mathrm{mg} / \mathrm{L}$ exceeds the US Environmental Protection Agency (EPA) aesthetic standard and is 
considered unacceptable for human consumption due to a metallic taste or staining of plumbing fixtures and clothes (US EPA, 2012). Many regions of the United States have Fe levels in groundwater that exceed the $0.3 \mathrm{mg} / \mathrm{L}$ Fe guideline (Mirlohi et al., 2011). Socha et al. (2003) recommended that Fe in drinking water for dairy cows should be less than $0.4 \mathrm{mg} / \mathrm{L}$ and reported that $41 \%$ of the 2,437 water samples collected throughout the United States exceeded that concentration. Observed water Fe ranged from 0.79 to $123 \mathrm{mg} / \mathrm{L}$ (Socha et al., 2003).

Excess iron available in the intestinal tract can interfere with absorption of other minerals and may cause oxidative stress, bacterial infection, diarrhea, and reduced weight gain (Coup and Campbell, 1964; Standish et al., 1971; Bullen et al., 1978; McGuire et al., 1985; Hansen et al., 2010). Genther and Beede (2013) reported lower water intake in lactating cows abomasally infused with ferrous lactate equivalent to $8 \mathrm{mg}$ of $\mathrm{Fe} / \mathrm{L}$ of drinking water. Iron is the third most frequent and important anti-quality consideration for dairy cattle and $\mathrm{Fe}$ toxicity is sometimes exacerbated in transition cows and fresh cows (Beede, 2005).

We hypothesized that because Fe in ferrous form can be more easily absorbed than Fe in ferric form, high doses of ferrous lactate would affect cow health and production performance. With its ability to complex with $\mathrm{P}$, high $\mathrm{Fe}$ in water might also compromise absorption of $\mathrm{P}$. The objective of this experiment was to determine the effects of abomasal infusion of ferrous lactate on production, nutrient digestion, and $\mathrm{P}$ absorption in lactating dairy cows.

\section{MATERIALS AND METHODS}

\section{Animals, Experimental Design, and Sample Collection}

All protocols and procedures were approved by the Virginia Tech Institutional Animal Care and Use Committee (Blacksburg). Four ruminally cannulated early lactation cows $(2$ Holstein and 2 Holstein $\times$ Jersey $)$ averaging 56 DIM $(\mathrm{SD}=27)$ were fed a basal diet containing $0.39 \% \mathrm{P}$, providing $100 \%$ of the calculated $P$ requirement (NRC, 2001). Treatments (abomasal infusion of $0,200,500$, or 1,250 $\mathrm{mg}$ of $\mathrm{Fe} / \mathrm{d}$ as ferrous lactate solution) were imposed in a $4 \times 4$ Latin square design with 14-d periods. Treatments were formulated to approximate $0,2,5$, or $12.5 \mathrm{mg}$ of $\mathrm{Fe} / \mathrm{L}$ concentrations in drinking water, assuming water intake of 100 $\mathrm{L} / \mathrm{d}$. The ingredient and nutrient composition of the experimental diets are shown in Table 1.

Cows were individually fed in Calan doors (American Calan Inc., Northwood, NH) once daily at $1200 \mathrm{~h}$ on
Table 1. Ingredient and nutrient ${ }^{1}$ composition of experimental diets

\begin{tabular}{lc}
\hline Item & \% of DM \\
\hline Corn silage & 40.4 \\
Grass hay (mid bloom) & 14.0 \\
Dry ground corn grain & 12.4 \\
Grass/legume mix silage & 6.1 \\
Wet brewers grain & 3.31 \\
Hominy feed & 4.20 \\
Soybean meal (48\% CP) & 6.95 \\
Cottonseed meal & 4.15 \\
Mineral and vitamin mix ${ }^{2}$ & 2.57 \\
Pro-Lak & 2.12 \\
Wheat middlings & 1.74 \\
Dehydrated molasses & 0.92 \\
Bentonite & 0.48 \\
Animal fat & 0.46 \\
Urea & 0.23 \\
\hline
\end{tabular}

${ }^{1}$ Total ration-formulated nutrient concentrations (DM basis) were 1.60 Mcal of $\mathrm{NE}_{\mathrm{L}} / \mathrm{kg}, 15.0 \% \mathrm{CP}, 34.7 \% \mathrm{NDF}, 17.5 \% \mathrm{ADF}, 0.66 \% \mathrm{Ca}$, $0.39 \% \mathrm{P}$, and $651 \mathrm{mg}$ of $\mathrm{Fe} / \mathrm{kg}$.

${ }^{2}$ Mineral and vitamin mix (DM basis): $41.51 \%$ limestone, $22.64 \%$ sodium bicarbonate, $7.46 \%$ magnesium oxide; $11.2 \%$ Dynamate (The Mosaic Co., Plymouth, MN); $11.3 \%$ salt, $2.11 \%$ Availa-4 (Zinpro Corp., Eden Prairie, MN), 1.14\% Se (0.06\%), 0.59\% vitamin E-60,000 IU, 0.22\% Rumensin 90 (Elanco Animal Health, Indianapolis, IN), and $1.79 \%$ vitamin $\mathrm{ADE}$

${ }^{3}$ Dairy bypass protein supplement (H. J. Baker \& Bro. Inc., Westport, CT).

d 1 to 7 and had constant access to feed except during milking. From d 8 to 14 of each period, cows were fed twice daily in individual tie-stalls and were milked twice daily at 0600 and $1800 \mathrm{~h}$, with continuous access to diet and water (drinking water Fe concentration 0.06 $\mathrm{mg} / \mathrm{L}$ ). Feed was offered at 5 to $10 \%$ in excess of the previous day's intake (wet basis). Starting from $1800 \mathrm{~h}$ on $\mathrm{d} 8$ and continuing through $1800 \mathrm{~h}$ on d 14 of each period, each cow was infused daily with $1 \mathrm{~L}$ of ferrous lactate solution $(0,200,500$, or $1,250 \mathrm{mg}$ of $\mathrm{Fe} / \mathrm{L})$ into the abomasum over a 24 -h period by using an infusion pump (Ardus Medical Inc., Cincinnati, OH). The solution was made of ferrous lactate in double-distilled water and the $\mathrm{Fe}$ concentration of the solution was monitored daily.

Samples of TMR and feed refusals were collected daily and stored at $-20^{\circ} \mathrm{C}$. Total fecal collection was conducted in the last $4 \mathrm{~d}$ of each period. At $1800 \mathrm{~h}$ on each day, feces from each cow was weighed and thoroughly blended. A representative sample was collected and stored at $-20^{\circ} \mathrm{C}$. Milk yield was recorded and milk samples were collected at 8 consecutive milkings from d 11 to 14 . Blood samples were obtained at $1200 \mathrm{~h}$ on d 13 and 14 of each period from the coccygeal vessel and saved in Vacuette tubes (Greiner Bio-One North America Inc., Monroe, NC). Serum was separated immediately by centrifugation at $1,850 \times g$ for $10 \mathrm{~min}$ at $4^{\circ} \mathrm{C}$ and stored at $-20^{\circ} \mathrm{C}$. 


\section{Laboratory Analysis}

Feed, feed refusals, and fecal samples were thawed at room temperature, dried at $55^{\circ} \mathrm{C}$ in a forced-air oven (Thermo Scientific Precision 645; Thermo Scientific, Danville, IN) and ground through a 1-mm screen in a Wiley mill (Arthur H. Thomas Co., Philadelphia, PA). Ground feed, feed refusals, and feces were analyzed in duplicate for DM, ash, total Kjeldahl N (AOAC, 1984), $\mathrm{NDF}$ (heat-stable $\alpha$-amylase and $\mathrm{Na}_{2} \mathrm{SO}_{3}$ were used), and ADF according to Van Soest et al. (1991). Ground feed, feed refusals, and fecal samples were ground further through a $0.2-\mathrm{mm}$ screen (Z-grinder; Retsch Inc., Newtown, PA) and analyzed for total P and inorganic $\mathrm{P}(\mathbf{P i})$ using the yellow molybdovanadate method and molybdate blue method (AOAC, 1984). Milk samples were analyzed for fat, protein, lactose, MUN, SCC (DHIA, Blacksburg, VA), and total P. Concentration of serum $\mathrm{Pi}$ was analyzed in a 96-well plate using the spectrophotometer (Eon Microplate Spectrophotometer; BioTek Instruments Inc., Winooski, VT). An aliquot of the acid digests of feed, feces, and milk samples were analyzed for $\mathrm{Ca}$ and $\mathrm{Fe}$ using inductively coupled plasma atomic emission spectroscopy (Ciros Vision model; Spectro Analytical Instruments Inc., Mahwah, NJ).

Feed samples were composited by period and feces samples composited by cow $\times$ period and analyzed for inositol hexaphosphate (IP6) following the method of Ray et al. (2012a). Briefly, 0.25 M NaOH-0.05 $M$ EDTA was used to extract dried ground samples and then extracts were acidified with $\mathrm{HCl}-\mathrm{HF}$ acid solution $(500 \mu \mathrm{L}$ of $6 \mathrm{M} \mathrm{HCl}$ and $1.2 M \mathrm{HF}$ added to 5 $\mathrm{mL}$ of sample extract). Acidified extracts were stored overnight at $4^{\circ} \mathrm{C}$ and then centrifuged at $30,000 \times g$ for $20 \mathrm{~min}$ at $4^{\circ} \mathrm{C}$. Clear supernatants were passed through methanol-conditioned C-18 columns (Sep-Pak Plus; Waters Corp., Milford, MA) and a $0.2-\mu \mathrm{m}$ ion chromatography (IC) membrane [polytetrafluoroethylene (PTFE) filter; IC Millex-LG; Fisher, Pittsburgh, PA] continuously into Dionex sample vials (Dionex Corp., Sunnyvale, CA) for high-performance ionic chromatography (HPIC) analysis.

\section{Statistical Analysis}

All data were analyzed using PROC GLIMMIX of SAS (SAS Institute, 2008) with the following model:

$$
\mathrm{Y}_{\mathrm{ijk}}=\mu+\mathrm{T}_{\mathrm{i}}+\mathrm{P}_{\mathrm{j}}+\mathrm{C}_{\mathrm{k}}+\varepsilon_{\mathrm{ijk}}
$$

where $\mathrm{Y}_{\mathrm{ijk}}=$ measured response, $\mu=$ overall mean, $\mathrm{T}_{\mathrm{i}}=$ fixed effect of treatment ( $\mathrm{i}=1$ to 4$), \mathrm{P}_{\mathrm{j}}=$ fixed effect of period ( $\mathrm{j}=1$ to 4$), \mathrm{C}_{\mathrm{k}}=$ random effect of cow $(\mathrm{k}=1$ to 4$)$, and $\varepsilon_{\mathrm{ijk}}=$ residual error. The random effect of cow was used to test treatment effects and preplanned contrasts were used to evaluate linear and quadratic treatment effects. Differences were declared significant at $P<0.05$ and trends at $P<0.10$. Results are reported as least squares means.

\section{RESULTS AND DISCUSSION}

\section{DMI and Digestibility}

Assuming the 0.1 absorption coefficient for $\mathrm{Fe}$ in feedstuffs assigned by the NRC (2001) and 100\% availability for infused $\mathrm{Fe}$, available Fe from the diet plus infusate in the current study ranged from 65 to 120 $\mathrm{mg} / \mathrm{kg}$ of DM. Effects of treatment on DMI were not observed (Table 2). Infusion of ferrous lactate into the abomasum did not affect NDF or nitrogen intake (Table 2 ). However, digestibility of DM, NDF, and nitrogen were all decreased linearly with increasing abomasal infusion of ferrous lactate $(P<0.01$; Table 2$)$. Similar to these observations, it was reported that DMI was not affected with 28.2 to $63.6 \mathrm{mg}$ of available $\mathrm{Fe} / \mathrm{kg}$ of DM from feedstuffs and supplemental organic Fe-amino acid complex (Weiss et al., 2010), assuming absorption coefficients for Fe in feedstuffs and supplemental complex of 0.1 and 1 , respectively.

The reductions in NDF, nitrogen, and DM digestibility with increasing abomasally infused ferrous lactate may be due to alterations in the microbial population of the large intestine. Excessive Fe supplementation or iron contamination of feeds has been shown to decrease microbial activity in the rumen, adversely influencing ruminal digestive processes (Hubbert et al., 1958). Martinez and Church (1970) tested effects of Fe addition on in vitro rumen cellulose digestion and observed that $100 \mathrm{mg}$ of $\mathrm{Fe} / \mathrm{L}$ in the incubation medium caused a $25 \%$ decrease in cellulose digestibility compared with controls. Similarly, with supplemental Fe between 100 and $1,000 \mathrm{mg} / \mathrm{L}$ of in vitro culture medium, DM digestion was decreased by up to $36 \%$ compared with controls (Harrison et al., 1992). In the current study, increasing available $\mathrm{Fe}$ in the digestive tract may have caused a similar adverse effect on the microbial population in the large intestine as observed in those studies focused on the rumen bacteria, explaining the negative effect of $\mathrm{Fe}$ infusion on total-tract nutrient digestion. Alternatively, Fe toxicity has been shown to cause diarrhea (NRC, 2001), which may increase the passage rate of the feed in the digestive tract, thus reducing total-tract nutrient digestibility. In the current study, no apparent change was observed in feces consistency with treatment. 
Table 2. Effect of abomasal infusion of ferrous lactate on nutrient intake and digestibility

\begin{tabular}{|c|c|c|c|c|c|c|c|c|}
\hline Item & \multicolumn{4}{|c|}{ Iron in infused solution, ${ }^{1} \mathrm{mg} / \mathrm{d}$} & $\mathrm{SE}$ & \multicolumn{3}{|c|}{$P$-value } \\
\hline DMI, kg/d & 23.1 & 22.3 & 23.1 & 22.7 & 0.43 & 0.27 & 0.67 & 0.98 \\
\hline DM digestibility, \% & 68.5 & 69.0 & 67.0 & 67.0 & 0.76 & 0.01 & 0.007 & 0.18 \\
\hline $\mathrm{NDF}$ intake, $\mathrm{kg} / \mathrm{d}$ & 8.01 & 7.73 & 7.99 & 7.84 & 0.15 & 0.28 & 0.66 & 0.97 \\
\hline NDF digestibility, $\%$ & 38.2 & 38.3 & 36.2 & 36.2 & 0.79 & 0.01 & 0.006 & 0.08 \\
\hline
\end{tabular}

${ }^{1}$ Treatments were formulated to approximate $0,2,5$, or $12.5 \mathrm{mg}$ of $\mathrm{Fe} / \mathrm{L}$ concentrations in drinking water, assuming water intake of $100 \mathrm{~L} / \mathrm{d}$.

\section{Phosphorus Intake and Absorption}

No effects of treatment on intake or apparent totaltract digestion of total $\mathrm{P}, \mathrm{Pi}$, or phytate $\mathrm{P}$ were observed (Table 3). Although high Fe intake has been shown to reduce $\mathrm{P}$ availability in chicks (Deobald and Elvehjem, 1935) and piglets (Furugouri, 1972), research examining the effect of iron intake on $\mathrm{P}$ utilization in dairy cattle is scarce. Iron phosphate complexes precipitate out in the intestinal tract of dairy cattle, reducing Fe availability (Miller, 1981); thus, the availability of phosphate is reduced too. It has been suggested that increasing dietary P might be an efficient way to prevent Fe toxicity (Standish et al., 1971; Rosa et al., 1982). In growing lambs consuming a low-Ca and low-P diet, high dietary Fe (350 and 600 vs. $100 \mathrm{mg} / \mathrm{kg}$ in the basal diet) had no negative effects on apparent absorption and retention of P (Mejía Haro et al., 2009). Cattle grazing pastures maybe exposed to high Fe through forage or soil ingestion (Spears, 2008), but the current study provides no evidence of negative effect of available Fe on $\mathrm{P}$ absorption.

The concentration of serum $\mathrm{Pi}$ was in the normal range $(6.07-6.82 \mathrm{mg} / \mathrm{dL})$ and was not affected by treat- ment, further evidence of the lack of effect of infused Fe on absorption of P. In lambs, supplementation of 1,200 $\mathrm{mg}$ of $\mathrm{Fe} / \mathrm{kg}$ of DM as ferrous carbonate decreased plasma $\mathrm{P}$ concentration slightly and reduced $\mathrm{Cu}$ stores, $\mathrm{Cu}$ transport, and storage protein without affecting bone ash (Prabowo et al., 1988). In calves, increasing dietary supplementation of ferric citrate (from 100 to 2,000 mg/ $\mathrm{kg}$ ) decreased plasma $\mathrm{Pi}$ without affecting weight gain and feed intake (Koong et al., 1970). In steers, plasma $\mathrm{Pi}$ was lower ( 4.0 vs. $6.9 \mathrm{mg} / \mathrm{dL}$ ) after $45 \mathrm{~d}$ of feeding $1,000 \mathrm{mg}$ of $\mathrm{Fe} / \mathrm{kg}$ of DM than when feeding $100 \mathrm{mg}$ of $\mathrm{Fe} / \mathrm{kg}$ of DM (Standish et al., 1971), but increased dietary P (0.46 vs. $0.23 \%$ ) reduced the detrimental effect of excessive $\mathrm{Fe}$ (less dark rumen color), indicating the interaction of the 2 elements. The current study was of much shorter duration and supplied less dietary Fe than the steer study (705 mg of Fe/ $\mathrm{kg}$ of DM in the highest infusion treatment vs. 1,000 $\mathrm{mg}$ of $\mathrm{Fe} / \mathrm{kg}$ of DM in the study of Standish et al., 1971).

Mineral-phytate complexes are resistant to hydrolysis by phytase (Maenz et al., 1999). Ferrous Fe is second to $\mathrm{Zn}$ in inhibitory potency to phytase hydrolysis at neutral $\mathrm{pH}$; ferric Fe ranks fourth. Insoluble complexes formed by phytic acid and $\mathrm{Fe}$ are not available for

Table 3. Effect of abomasal infusion of ferrous lactate on intake and digestibility of total $\mathrm{P}$, inorganic $\mathrm{P}$ (Pi), and phytate $\mathrm{P}$

\begin{tabular}{|c|c|c|c|c|c|c|c|c|}
\hline \multirow[b]{2}{*}{ Item } & \multicolumn{4}{|c|}{ Iron in infused solution, ${ }^{1} \mathrm{mg} / \mathrm{d}$} & \multirow[b]{2}{*}{$\mathrm{SE}$} & \multicolumn{3}{|c|}{$P$-value } \\
\hline & 0 & 200 & 500 & 1,250 & & Treatment & Linear & Quadratic \\
\hline Fecal, g/d & 51.4 & 49.9 & 53.4 & 52.3 & 1.24 & 0.13 & 0.22 & 0.30 \\
\hline Apparent total-tract digestibility, \% & 43.5 & 43.2 & 41.2 & 41.4 & 1.14 & 0.41 & 0.20 & 0.39 \\
\hline \multicolumn{9}{|l|}{$\mathrm{Pi}$} \\
\hline Apparent total-tract digestibility, $\%$ & 22.5 & 23.0 & 20.2 & 20.0 & 2.49 & 0.80 & 0.48 & 0.77 \\
\hline Serum $\mathrm{Pi}, \mathrm{mg} / \mathrm{dL}$ & 6.77 & 6.07 & 6.82 & 6.51 & 0.38 & 0.45 & 0.99 & 0.97 \\
\hline \multicolumn{9}{|l|}{ Phytate P } \\
\hline Intake, g/d & 35.6 & 34.3 & 35.6 & 34.9 & 0.70 & 0.27 & 0.69 & 0.94 \\
\hline Fecal, g/d & 1.01 & 0.96 & 0.91 & 0.87 & 0.10 & 0.27 & 0.08 & 0.41 \\
\hline Apparent total-tract digestibility, \% & 97.2 & 97.2 & 97.5 & 97.5 & 0.24 & 0.22 & 0.08 & 0.40 \\
\hline
\end{tabular}

${ }^{1}$ Treatments were formulated to approximate $0,2,5$, or $12.5 \mathrm{mg}$ of $\mathrm{Fe} / \mathrm{L}$ concentrations in drinking water, assuming water intake of $100 \mathrm{~L} / \mathrm{d}$. 
Table 4. Effect of abomasal infusion of ferrous lactate on milk yield and composition

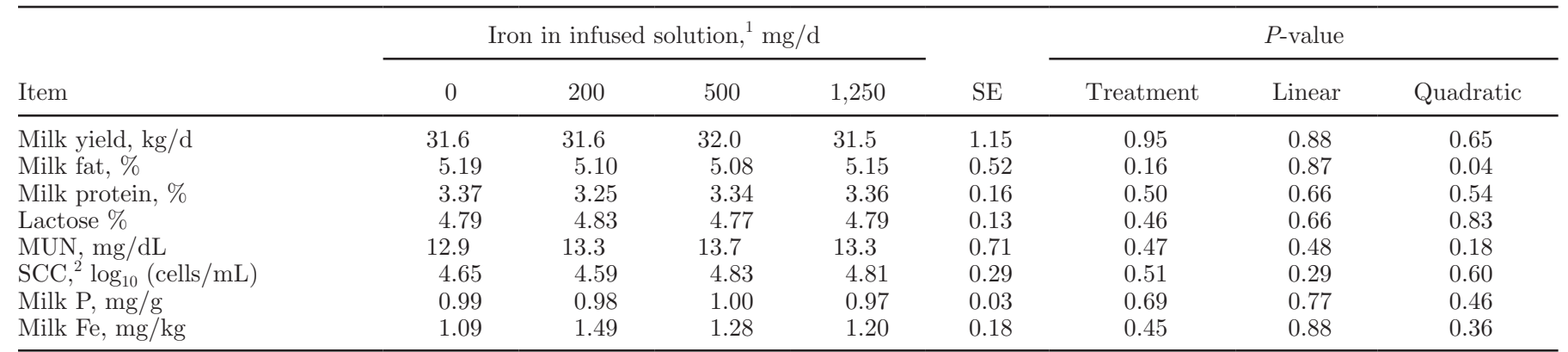

${ }^{1}$ Treatments were formulated to approximate $0,2,5$, or $12.5 \mathrm{mg}$ of Fe/L concentrations in drinking water, assuming water intake of $100 \mathrm{~L} / \mathrm{d}$.

${ }^{2}$ Milk SCC (cells $/ \mathrm{mL}$ ) was $\log _{10}$ transformed to normalize the data.

absorption under the $\mathrm{pH}$ conditions of the small intestine (Minihane and Rimbach, 2002). A portion of any phytate flowing to the large intestine of dairy cattle is digested by the microbes residing there (Ray et al., $2012 \mathrm{~b}$ ). We expected that infused Fe would decrease phytate degradability to some extent in the large intestine, thus decreasing total-tract phytate digestibility. Despite a tendency for phytate $\mathrm{P}$ in feces to decrease $(P=0.08)$ with increasing $\mathrm{Fe}$ infusion, the magnitude of the change was small and phytate digestibility was not significantly affected by treatment. Bremner and Dalgarno (1973) observed lower availability of Fe from Fe phytate than from 3 soluble sources $\left(\mathrm{FeSO}_{4}\right.$, ferric citrate, and ferric-EDTA) in calves, with no differences between the 3 soluble Fe sources.

\section{Milk Production and Composition}

Milk yield, milk protein, milk lactose, SCC, and MUN were unaffected by treatment (Table 4). A quadratic effect of treatment on milk fat was observed $(P=0.04$; Table 4) but the magnitude of the change was small. Iron infusion did not affect concentration of $\mathrm{P}$ or Fe in milk. Others have also observed no change in milk yield or composition with supplementation of $30 \mathrm{mg}$ of $\mathrm{Fe} / \mathrm{kg}$ of DM (Weiss et al., 2010) or $500 \mathrm{mg}$ of $\mathrm{Fe} / \mathrm{kg}$ of DM (Chase et al., 2000). Lowered milk and fat production in dairy cattle dosed orally with 30 to $60 \mathrm{~g}$ of $\mathrm{Fe} / \mathrm{d}$ in the form of ferric hydroxide (Coup and Campbell, 1964) was reported. Genther and Beede (2013) reported lowered water intake by lactating cows with $8 \mathrm{mg}$ of $\mathrm{Fe} / \mathrm{L}$ drinking water. Water $\mathrm{Fe}$ of the same magnitude as in the current study might reduce water intake due to palatability, potentially affecting production.

In the current study, increasing doses of Fe infusion did not affect milk SCC, suggesting that up to 1,250 $\mathrm{mg}$ of ferrous $\mathrm{Fe} / \mathrm{d}$ is safe for early lactation dairy cattle. In the study of Weiss et al. (2010), cows receiving supplemental Fe $(30 \mathrm{mg} / \mathrm{kg})$ had lower SCC ( $\log _{10}$ cells $/$
$\mathrm{mL}$ ) than controls (4.37 vs. 4.62), but the magnitude of the response was so low as to have little economic significance.

\section{CONCLUSIONS}

Abomasal infusion of up to 1,250 mg of Fe/d from ferrous lactate in early lactation cows fed Fe-adequate diets did not affect DMI, $\mathrm{P}$ intake, $\mathrm{P}$ absorption, milk composition, or milk production. However, digestibility of DM, NDF and nitrogen were decreased with increasing Fe infusion. In the short-term, water Fe up to 12.5 $\mathrm{mg} / \mathrm{L}$ did not affect production or P status of lactating cows.

\section{REFERENCES}

AOAC (Association of Official Analytical Chemists). 1984. Official Methods of Analysis. 14th ed. AOAC, Arlington, VA.

Beede, D. K. 2005. Assessment of water quality and nutrition for dairy cattle. Pages 1-19 in Proc. Mid-South Ruminant Nutr. Conf., Arlington, TX. Texas Animal Nutrition Council, Dallas, TX.

Bremner, I., and A. C. Dalgarno. 1973. Iron metabolism in the veal calf. The availability of different iron compounds. Br. J. Nutr. 29:229-243.

Bullen, J. J., H. J. Rogers, and E. Griffiths. 1978. Role of iron in bacterial infection. Curr. Top. Microbiol. Immunol. 80:1-35.

Chase, C. R., D. K. Beede, H. H. Van Horn, J. K. Shearer, T. C. J. Wilcox, and G. A. Donovan. 2000. Responses of lactating dairy cows to copper source, supplementation rate, and dietary antagonist (iron). J. Dairy Sci. 83:1845-1852.

Coup, M. R., and A. G. Campbell. 1964. The effect of excessive iron intake upon the health and production of dairy cows. J. Agric. Res. 7:624-638.

Deobald, H. J., and C. A. Elvehjem. 1935. The effect of feeding high amounts of soluble iron and aluminum salts. Am. J. Physiol. 111:118-123.

Frazer, D. M., and G. J. Anderson. 2005. Iron imports. I. Intestinal iron absorption and its regulation. Am. J. Physiol. Gastrointest. Liver Physiol. 289:G631-G635.

Furugouri, K. 1972. Effect of elevated dietary levels of iron on iron store in liver, some blood constituents and phosphorus deficiency in young swine. J. Anim. Sci. 34:573-577.

Genther, O. N., and D. K. Beede. 2013. Preference and drinking behavior of lactating dairy cows offered water with different concentrations, valences, and sources of iron. J. Dairy Sci. 96:1164-1176. 
Hansen, S. L., M. S. Ashwell, A. J. Moeser, R. S. Fry, M. D. Knutson, and J. W. Spears. 2010. High dietary iron reduces transporters involved in iron and manganese metabolism and increases intestinal permeability in calves. J. Dairy Sci. 93:656-665.

Hansen, S. L., and J. W. Spears. 2009. Bioaccessibility of iron from soil is increased by silage fermentation. J. Dairy Sci. 92:2896-2905.

Harrison, G. A., K. A. Dawson, and R. W. Hemken. 1992. Effects of high iron and sulfate ion concentrations on dry matter digestion and volatile fatty acid production by ruminal microorganisms. J. Anim. Sci. 70:1188-1194.

Hubbert, F., Jr., E. Cheng, and W. Burroughs. 1958. Mineral requirement of rumen microorganisms for cellulose digestion in vitro. J. Anim. Sci. 17:559-568.

Koong, L.-J., M. B. Wise, and E. R. Barrick. 1970. Effect of elevated dietary levels of iron on the performance and blood constituents of calves. J. Anim. Sci. 31:422-427.

Maenz, D. D., C. M. Engele-Schaan, R. W. Newkirk, and H. L. Classen. 1999. The effect of minerals and mineral chelators on the formation of phytase-resistant and phytase-susceptible forms of phytic acid in solution and in a slurry of canola meal. Anim. Feed Sci. Technol. 81:177-192.

Martinez, A., and D. C. Church. 1970. Effect of various mineral elements on in vitro rumen cellulose digestion. J. Anim. Sci. 31:982990.

McGuire, S. O., W. J. Miller, R. P. Gentry, M. W. Neathery, S. Y. Ho, and D. M. Blackmon. 1985. Influence of high dietary iron as ferrous carbonate and ferrous sulfate on iron metabolism in young calves. J. Dairy Sci. 68:2621-2628.

Mejía Haro, I., R. D. Brink, and J. Mejía Haro. 2009. Effects of inclusion of different levels of iron in lamb diets on apparent absorption and retention of phosphorus. J. Anim. Vet. Adv. 8:19-22.

Miller, W. J. 1981. Mineral and vitamin nutrition of dairy cattle. J. Dairy Sci. 64:1196-1206.

Minihane, A. M., and G. Rimbach. 2002. Iron absorption and the iron binding and anti-oxidant properties of phytic acid. Int. J. Food Sci. Technol. 37:741-748.

Mirlohi, S., A. M. Dietrich, and S. E. Duncan. 2011. Age-associated variation in sensory perception of iron in drinking water and the potential for overexposure in the human population. Environ. Sci. Technol. 45:6575-6583.

NRC. 2001. Nutrient Requirements of Dairy Cattle. 7th rev. ed. Natl. Acad. Press, Washington, DC.

Prabowo, A., J. W. Spears, and L. Goode. 1988. Effects of dietary iron on performance and mineral utilization in lambs fed a forage-based diet. J. Anim. Sci. 66:2028-2035.
Ray, P. P., C. Shang, R. O. Maguire, and K. F. Knowlton. 2012a. Quantifying phytate in dairy digesta and feces: Alkaline extraction and high-performance ion chromatography. J. Dairy Sci. 95:3248-3258.

Ray, P. P., C. Shang, R. E. Pearson, and K. F. Knowlton. 2012b. Disappearance of infused phytate from the large intestine of dairy heifers. J. Dairy Sci. 95:5927-5935.

Rosa, I. V., P. R. Henry, and C. B. Ammerman. 1982. Interrelationship of dietary phosphorus, aluminum and iron on performance and tissue mineral composition in lambs. J. Anim. Sci. 55:1231-1240.

SAS Institute. 2008. SAS $/$ STAT $^{\circledast} 9.2$ User's Guide. SAS Institute Inc., Cary, NC.

Socha, M. T. S. M. Ensley, D. J. Tomlinson, and A. B. Johnson. 2003. Variability of water composition and potential impact on animal performance. Pages 85-96 in Proc. Intermountain Nutr. Conf. Utah State University, Logan.

Spears, J. W. 2008. Trace mineral nutrition-What is important and where do organic trace minerals fit in? Accessed Nov. 2, 2012. http:// animal.cals.arizona.edu/swnmc/Proceedings/2008/02Spears_08. pdf.

Standish, J. F., C. B. Ammerman, A. Z. Palmer, and C. F. Simpson. 1971. Influence of dietary iron and phosphorus on performance, tissue mineral composition and mineral absorption in steers. J. Anim. Sci. 33:171-178.

Standish, J. F., C. B. Ammerman, C. F. Simpson, F. C. Neal, and A. Z. Palmer. 1969. Influence of graded levels of dietary iron, as ferrous sulfate, on performance and tissue mineral composition of steers. J. Anim. Sci. 29:496-503.

Thomas, J. W. 1970. Metabolism of iron and manganese. J. Dairy Sci. 53:1107-1123.

Underwood, E. J., and N. F. Suttle. 1999. The Mineral Nutrition of Livestock. 3rd ed. CABI Publishing, New York, NY.

US EPA (Environmental Protection Agency). 2012. Secondary maximum contaminant level for drinking water. Accessed Jan. 13, 2012. http://water.epa.gov/drink/contaminants/secondarystandards. cfm.

Van Soest, P. J., J. B. Robertson, and B. A. Lewis. 1991. Methods for dietary fiber, neutral detergent fiber, and nonstarch polysaccharides in relation to animal nutrition. J. Dairy Sci. 74:3583-3597.

Weiss, W. P., J. M. Pinos-Rodríguez, and M. T. Socha. 2010. Effects of feeding supplemental organic iron to late gestation and early lactation dairy cows. J. Dairy Sci. 93:2153-2160. 